
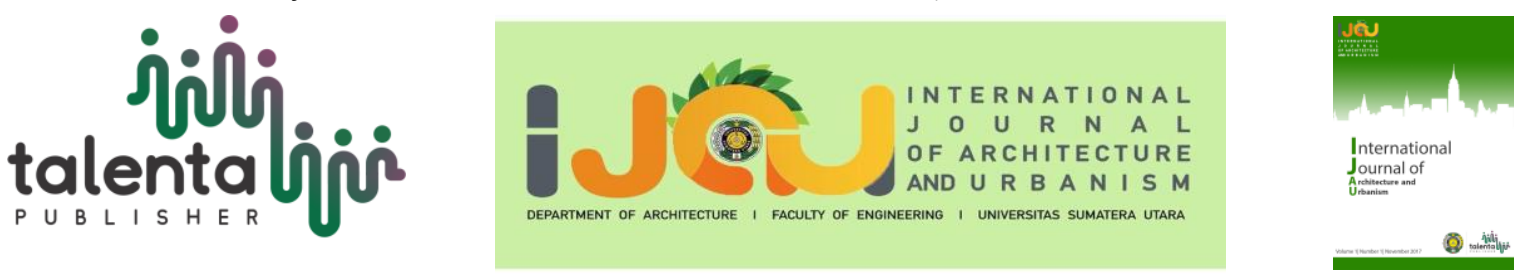

\title{
The Ecological Approach To The Study of Medan Belawan Sub District
}

\author{
Rara Ayu Rati Kumala Dewi ${ }^{1^{*}}$ \\ ${ }^{1}$ Urban And Regional Planning Department, Civil engineering and Planning Faculty, Bung Hatta \\ University, Padang, Indonesia
}

\begin{abstract}
The ecological approach is the study of the spatial and temporal relations of human beings as affected by the selective, distributive, and accommodative forces of the environment. This condition also stimulates industrial growth, both large, medium, small, and the housing industry. In 2019, it was noted that there were 28 large medium industries, 150 small industries, and 73 home industries. Industrial growth has stimulated the growth of settlements in this region where the growth of the settlements follows the growth of the industry itself. This has caused the area around the industry to have transformed into a densely populated area. The results of the study show that Medan Belawan Sub-District is an area that grows, and its development is influenced by the coast.
\end{abstract}

Keyword: ecology, approach, spatial structure

Received 28 Oktober 2020 | Revised 3 October 2020 | Accepted 15 November 2020

\section{Introduction}

Medan Belawan District is one of 21 sub-districts in the city of Medan, North Sumatra. Medan Belawan Sub District is one of the sub-districts in Medan City which has an area of $21.82 \mathrm{~km}^{2}$. The total population in Medan Belawan Sub District is 99,611 people. Medan Belawan Sub District consists of 6 villages namely Belawan Pulau Sicanang, Belawan Bahagia, Belawan Bahari, Belawan II, Bagan Deli, and Belawan I. Medan Belawan Sub District is located between 03-48 North Latitude and 98-42 East Longitude [1]. The boundaries of the Medan Belawan Sub District are as follows: North with Malacca Strait; South with Medan Labuhan Sub District; West with Deli Serdang Sub District; East with Deli Serdang Sub District (Figure 1).

\footnotetext{
*Corresponding author at: ${ }^{1}$ Urban And Regional Planning Department, Civil engineering and Planning Faculty, Bung Hatta University, Jl. Sumatera, Ulak Karang Utara 25133, Padang, Indonesia 


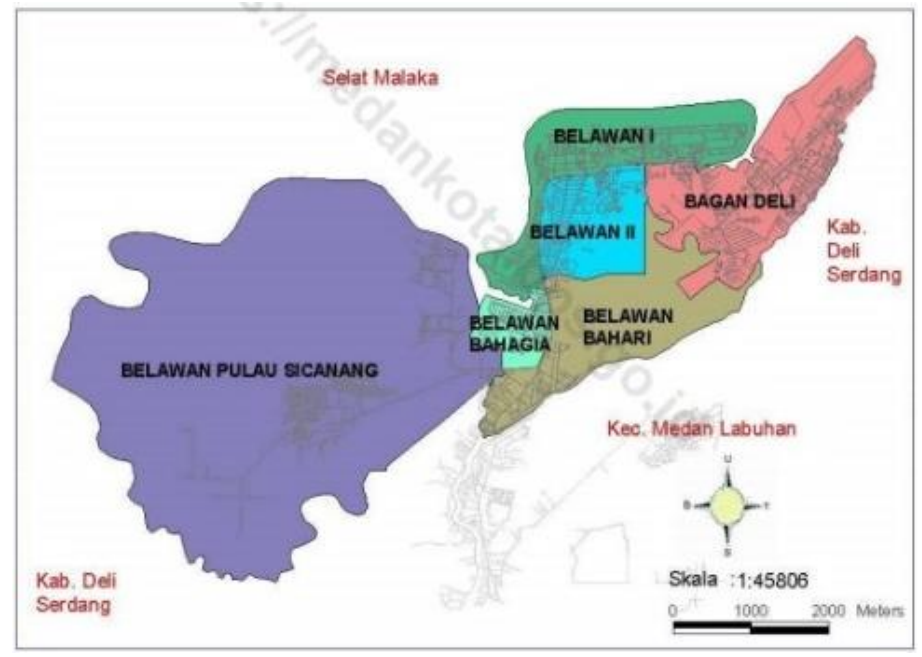

Figure 1 Administration Map

The geographical condition of Medan Belawan Sub District, which is located on the coast of Medan City, has made this sub-district designated as one of the marine transportation service centres. This condition also stimulates industrial growth, both large, medium, small, and the housing industry. The growth and development of this industry will certainly stimulate the growth of settlements in the region. Based on this condition, it is necessary to pay attention to how the spatial pattern in Medan Belawan Sub District using an ecological approach. Because besides being centred on the industry, Medan Belawan Sub District also has protected areas that need to be preserved.

\section{Literature Review}

Ecology is the study of the relationship of all living things, including people, to their biological and physical environments. Ecological planning then may be defined as the use of biophysical and sociocultural information to suggest opportunities and constraints for decision making about the use of the landscape [2]. The ecological approach is the study of the spatial and temporal relations of human beings as affected by the selective, distributive, and accommodative forces of the environment. This condition also stimulates industrial growth, both large, medium, small, and the housing industry [3]. The spatial structure is an arrangement of settlement centres and a network of infrastructure and facilities that functions as a support for the community's socioeconomic activities which hierarchically have functional relationships [4]. Urban morphology is the study of the form of human settlements and the process of their formation and transformation. The study seeks to understand the spatial structure and character of a metropolitan area, city, town or village by examining the patterns of its parts and the ownership or control and occupation [5]. Sustainable development has become a global and even national issue. The objective of sustainable development is essential to balance the three pillars of development, namely economic, social and environmental [6]. 


\section{Methodology}

This research will later examine the spatial structure of the Medan Belawan Sub District using an ecological approach. The research method used is the descriptive qualitative method. This research method aims to collect actual information in detail describing and explaining existing symptoms, identifying problems, or examining conditions in the study conducted [7].

Data collection techniques in this study were primary and secondary data surveys. The primary data survey was carried out by visiting and seeing the study location directly and looking at the satellite image map. The secondary data survey was conducted by collecting the required information from government agencies such as the online BPS of Medan City and Medan City Government. As well as collecting information from internet literature or previous research. The data needed are administrative maps, spatial pattern maps, geographic and demographic data. The primary data is the documentation pictures.

\section{Result and Discussion}

Based on the directions for the development of the Medan City spatial structure contained in the RPI2JM document of Medan City, it is stated that the Medan Belawan service sub-centre which functions as a sea transportation service centre, a centre for loading and unloading and importexport activities, a centre for defence and security services, a centre for industrial activities and centre fishery activities, are stipulated in Medan Belawan Sub District, to be precise at the train station at the Belawan Lama Port [8] (Figure 2).

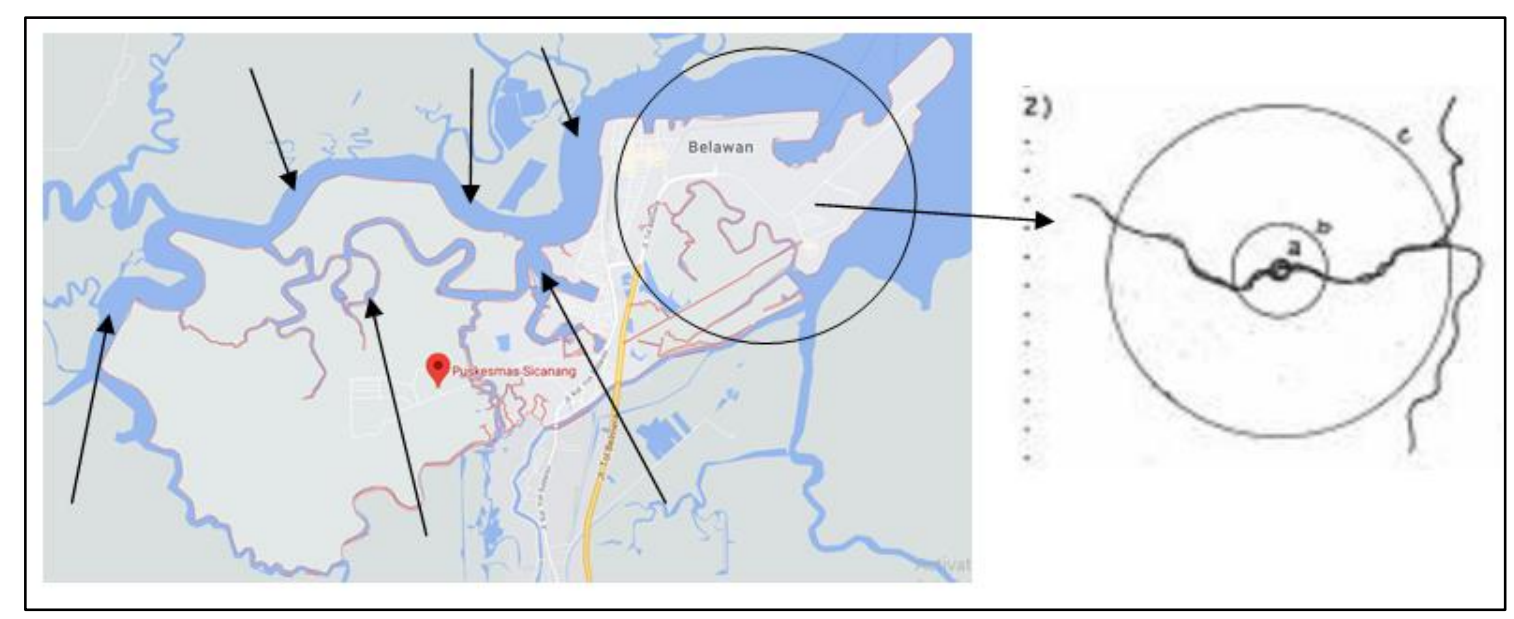

Figure 2 Ecological Approach Model

Ecology Architecture is a field that pays attention to the ecological condition of the surrounding natural environment so that the natural conditions of the environment are maintained and that the ecosystem is maintained [9]. 
Site aspect by paying attention to the preservation of the surrounding environment and saving the energy to be used. Aspects of form and mass structure by applying the locality and ecological value of the building. Structural and utility aspects with the use of local materials and water treatment efforts again [10].

Medan Belawan Sub District is a sub-district that has many rivers and is a sub-district that is located close to the bay. This condition then stimulates urban growth starting from the area around the bay. The urban growth continues with the characteristic land use is dominated by ports and industry. Starting from the bay area itself, industrial growth in Medan Belawan Sub District continues to increase with a pattern following the main road. The industry from the coast continues to grow until it dominates nearly half of the built area of Medan Belawan Sub District (Figure 3).

From various opinions on architectural design with an ecological approach, the point is, approaching architectural design problems by emphasizing the harmony of buildings with natural behavior, from the stage of establishment to age [11].

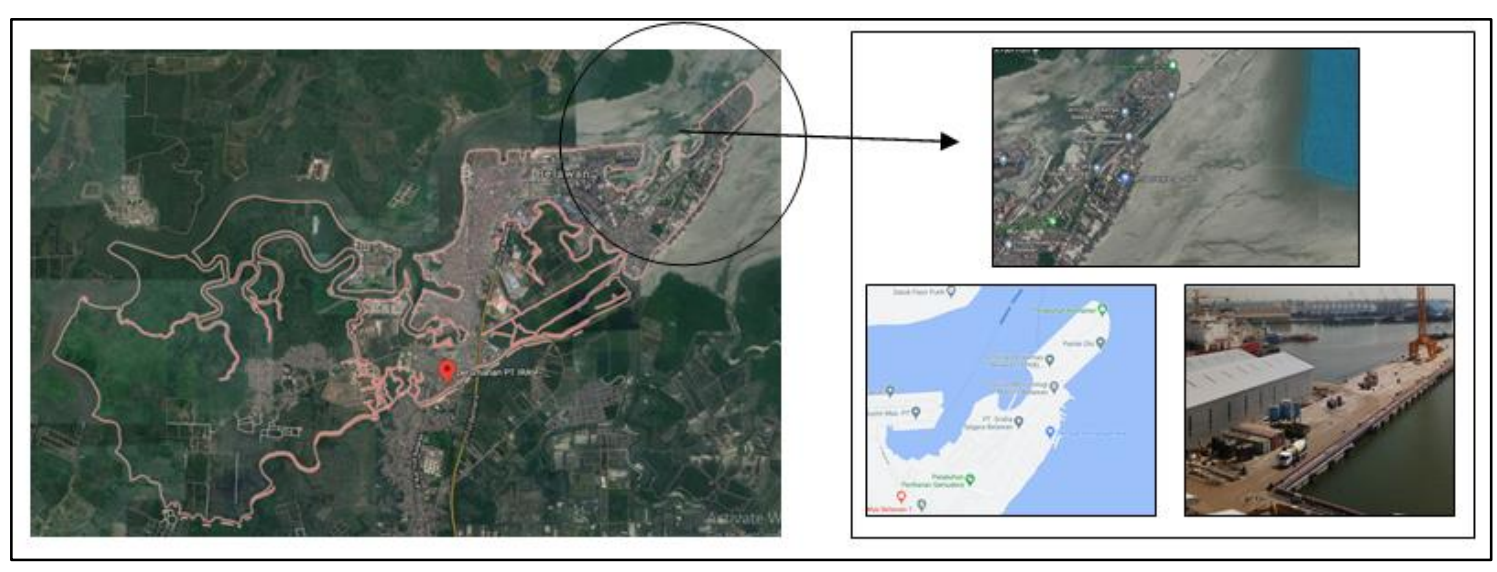

Figure 3 Medan Belawan Sub District Coastal Area

Under the direction of the spatial pattern, the existing condition of the Medan Belawan District does have many industries that are located from the bay border to spread along the main road. Industry becomes the main activity centre. In 2019, it was noted that there were 28 large medium industries, 150 small industries, and 73 home industries. Some of the existing industries are export-import, refineries, oil, fishery industry, and home industry (Figure 4). 


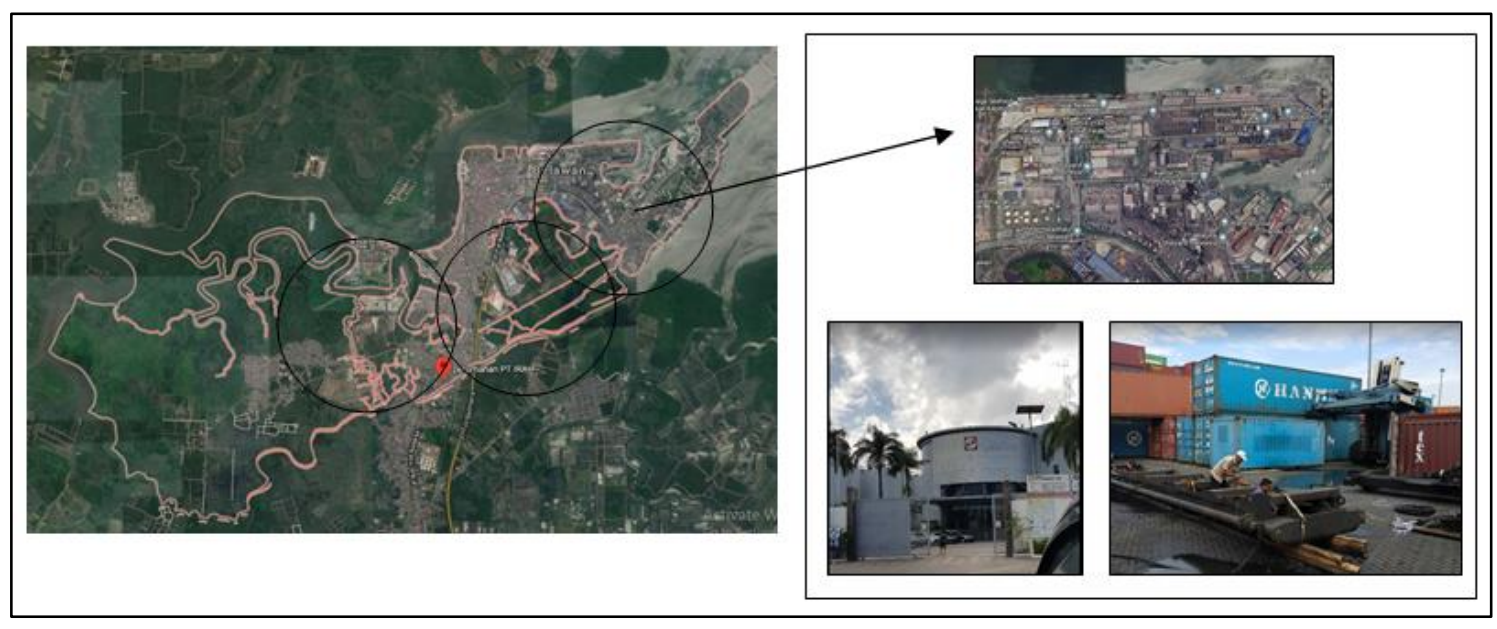

Figure 4 Industrial Growth

Ecological Design has the following principles: a) Save energy is to save the building to a minimum; b) Physical integration with the physical characteristics of the local ecology, including soil conditions, topography, groundwater, vegetation, climate and so on; c) Integration of these systems with natural processes, including how to use water, treatment and disposal of liquid waste, disposal systems from buildings and release of heat from buildings and so on; d) Integration of resource use that includes the sustainable use of natural resources; e) Natural air is designed to get natural air into a building; f) The solar orientation response is a response to the orientation of the sun making the building get the maximum light into the room, and can minimize excessive light; g) Humanism is creating comfort in buildings and inviting users to realize for savings [12].

As a result of the concentration of industrial activities in this area, the pattern of residential growth follows the growth of industrial activities. It can be seen that on the map below, red shows industrial areas while black shows residential areas. Settlements grow around industrial activities. The settlement density at these points continues to increase (Figure 5). 


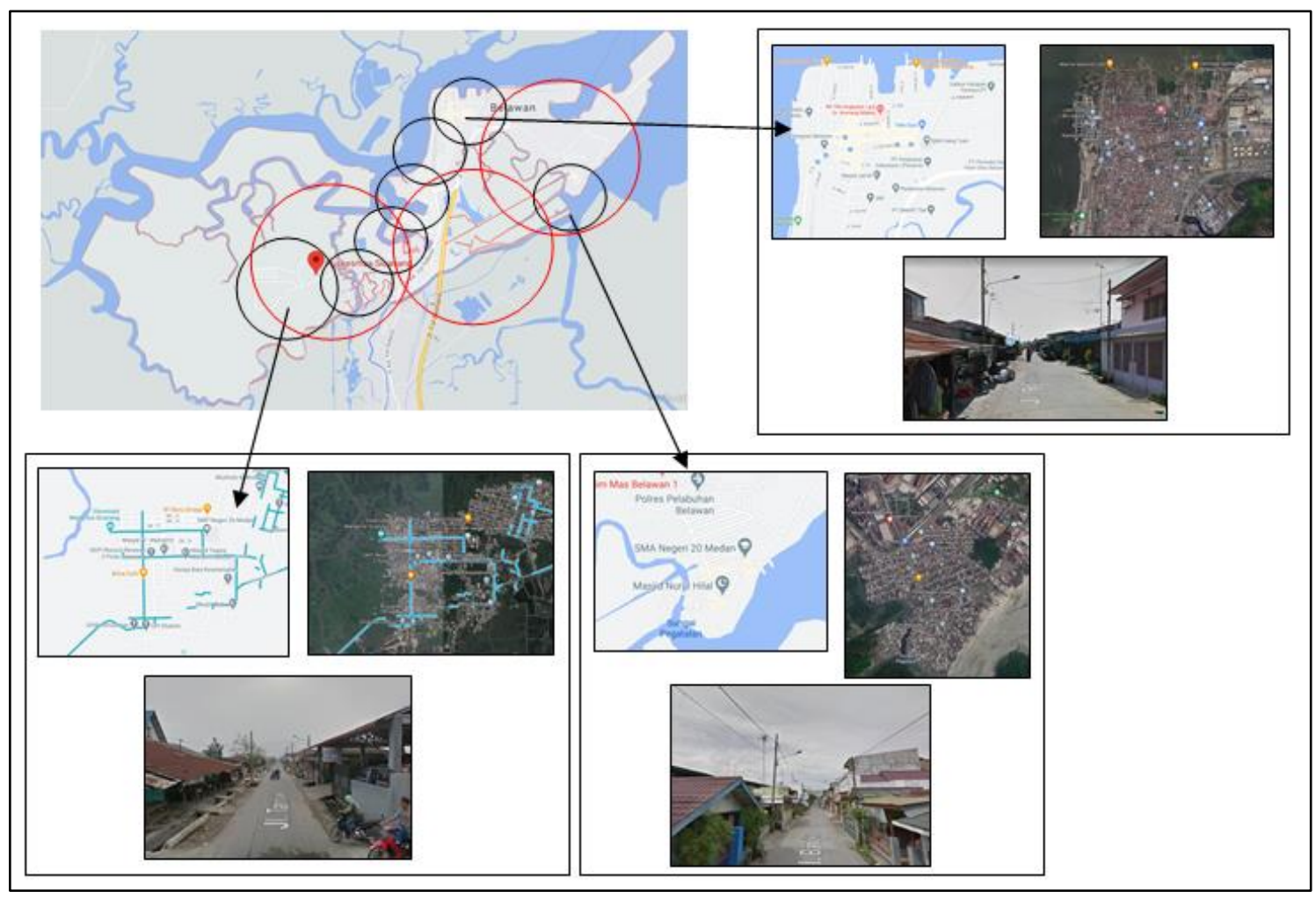

Figure 5 Residential Area Growth

Consequently, a rural tourism approach should be promoted in sustainable sound with the objectives of increasing environmental conservation, generating new local economic activities and providing jobs for local people. In many parts of the world, tourism is one of the rational options for rural development [13]. Industrial growth and settlement growth in Medan Belawan Sub District are likely to continue. This could lead to changes in land use due to continued development growth. In the image below, it can be seen that the settlement has reached a protected area.

The yellow circle is a mangrove protected area. This mangrove tour is precisely located on Jalan Pulau Sicanang, Belawan Sicanang Village. At this time, mangrove tourism is in danger of being closed due to several things including the absence of a land-use permit. As it is known that this tour is very useful not only in addition to preventing abrasion, mangrove ecotourism, which has been built since 2015, is also one of the mainstay natural tourist destinations in Medan City. Gunn and Var (2002) point out that spatially tourism destinations consist of basic elements namely gateway, community, corridor and attraction complex which should be managed in an integrative vision [14].

Changes in the quality of the aquatic environment greatly affect the distribution and life of marine life. Parameters that greatly affect the marine biota are temperature and salinity of the waters. Not only aquatic biota, salinity parameters also affect the typology of coastal ecosystems such as mangroves [15]. 
Changes in land use increased population, settlements and infrastructure. The magnitude of these driving factors triggers pressures on the ecological system, especially mangrove ecosystems and coastal systems [16]. In the vicinity of this area has begun to be crowded with settlements. This development movement will further encourage land-use change in protected areas if the correct application of the spatial pattern direction in the Medan Belawan Sub District is not applied (Figure 6).

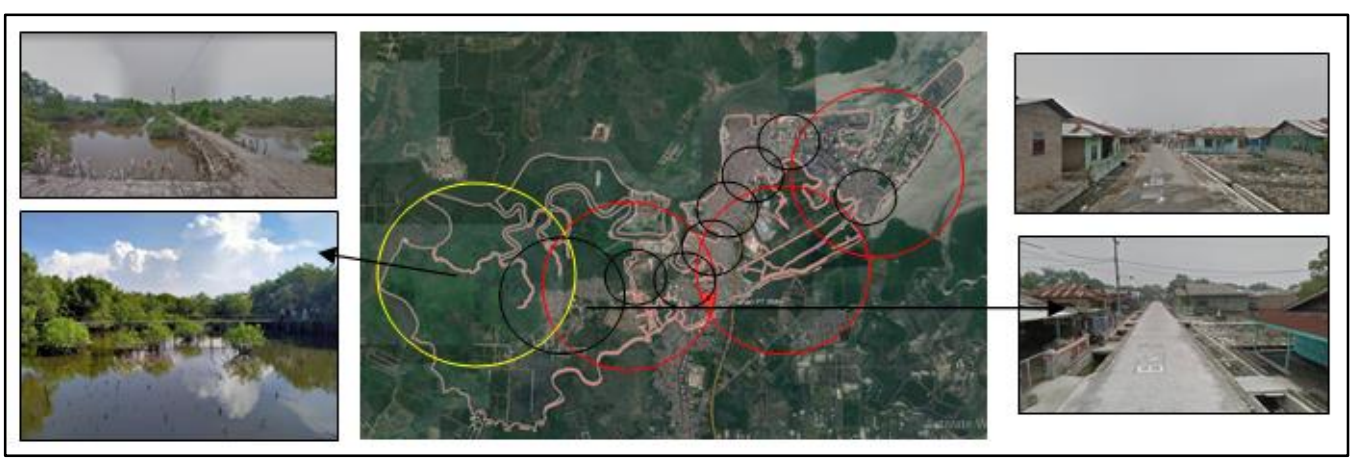

Figure 6 Movement Of Settlement Growth

The trade and service facilities in the study area are only located along the main road. It is known from the data from the Subdistrict in Medan Belawan Sub District Dalam Angka 2020 that the trade and service facilities are not yet busy enough. There are only two markets, 201 groups of shops and ten supermarkets. Meanwhile, the office facilities themselves have a scattered pattern and are not centred on a single point. When viewed from the rapid growth of industries and settlements in the eastern part, trade and services may also grow (Figure 7).

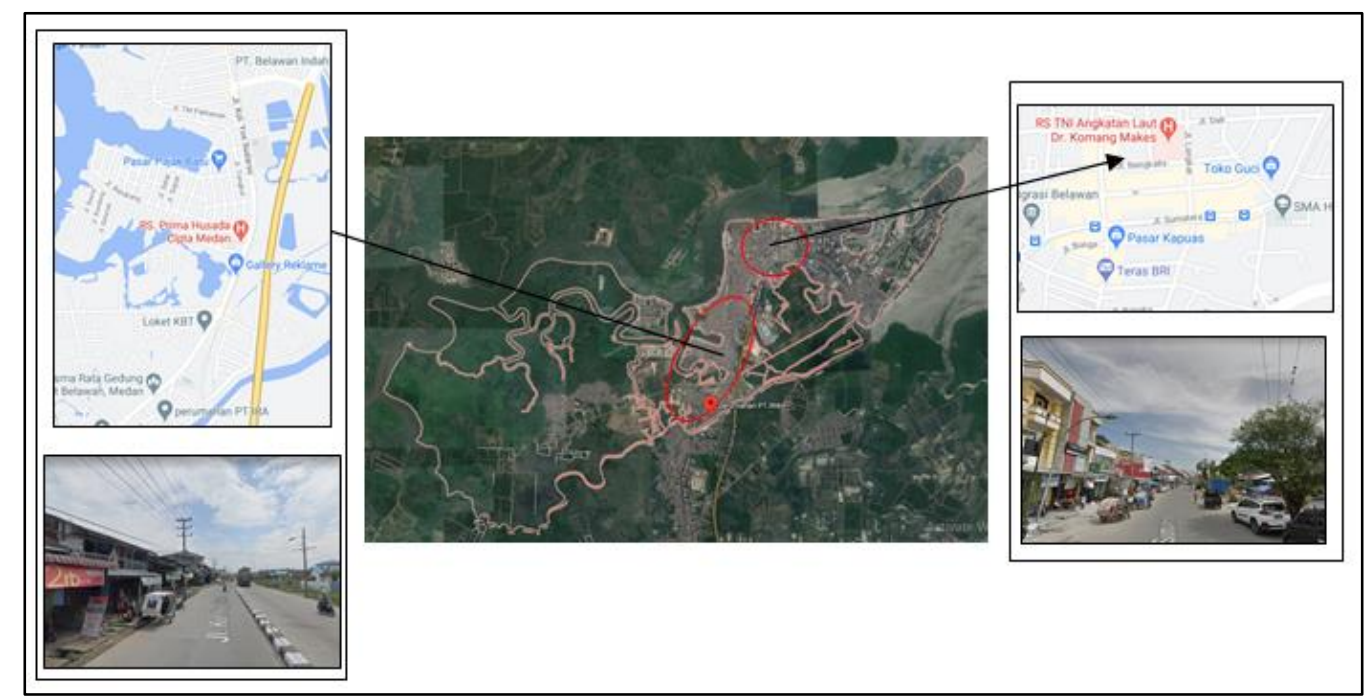

Figure 7 Trade And Service

\section{Conclusion}

Medan Belawan Sub District is an area located in the coastal area of Medan City and is a maritime area that is directly adjacent to the Malacca Strait. As stated in the RPIJM document 
for Medan City, it has been stated that Medan Belawan District is designated as a centre for transportation, trade, export-import, and other services. This will cause industry in the region to continue to grow. As explained above, settlements will continue to develop along with the development of industry in this area, where the growth of the settlements itself follows the growth of the industry itself. This has caused the area around the industry to have transformed into a densely populated area. This growth is likely to cause a movement of changes in spatial structure. The growth that was originally centred on the eastern region will move towards the west because of the increasing human need for shelter. It is feared that this will disrupt the preservation of protected areas in the Medan Belawan Sub District.

Ecological principles that review the architectural ecological planning patterns according to Heinz Frick are as follows: Creating green areas in development areas, using environmentally friendly materials, applying walls and roofs of buildings that are able to respond to weather well with natural processes, so that buildings can save energy, create buildings that do not damage the environment, the shape and proportion of buildings that are made can harmonize the conditions of the environment [17].

Medan Belawan Sub-District is an area surrounded by rivers. There are two rivers in the Medan Belawan sub-district. Development around the river is quite active, both in the form of settlements and industry. Medan Belawan city centre is also located close to the river (Figure 8).

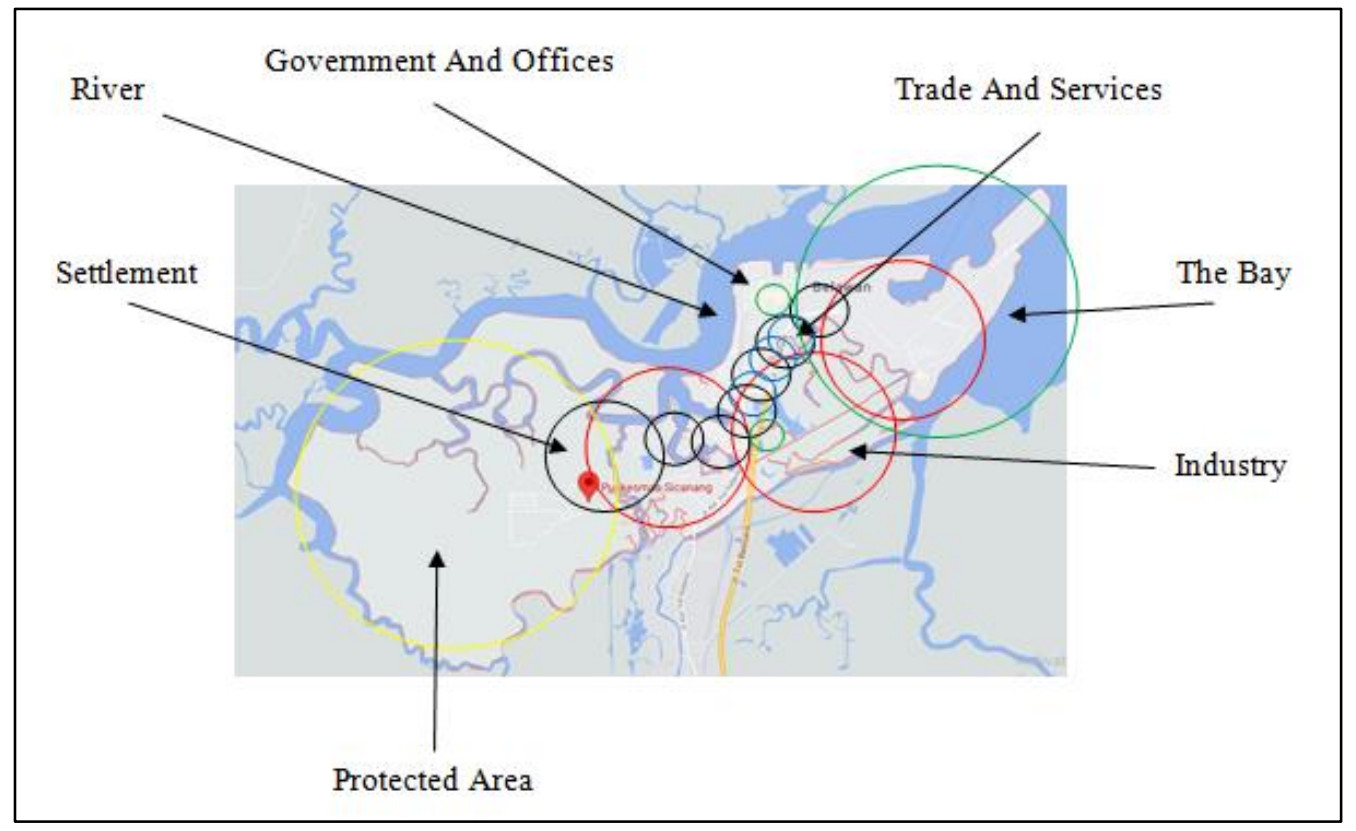

Figure 8 Spatial Structure

\section{REFERENCES}

[1] Medan City Statistical Centre, Medan Belawan Sub District Dalam Angka 2020. Medan: Nov, 2020. [Online]. 
https://medankota.bps.go.id/publication/2020/09/28/c6e52cb07673bb57436ff34f/kecamata n-medan-belawan-dalam-angka-2020.html. [Accessed: Oct. 28, 2020].

[2] F. R. Steiner, The Living Landscape: An Ecological Approach to Landscape Planning, 2nd ed. ISLAND PRESS, 2008. [Online] Available: Google Play e-book.

[3] S. Alwi, "Struktur Tata Ruang Kota," Slideplayer. Jan, 2015. [Online]. Available: https://slideplayer.info/slide/3281730/. [Accessed: Oct. 28, 2020].

[4] Indonesian Ministry Of Finance, "Constitution of The Republic of Indonesia Number 26 of 2007 about Spatial Planning," Indonesian Ministry Of Finance, 2007. [Online]. Available: http://jdih.kemenkeu.go.id/fullText/2007/26TAHUN2007UU.htm [Accessed: Oct. 28, 2020].

[5] Moudon, Anne Vemez, "Urban morphology as an emerging interdisciplinary field". Urban Morphology. 1 (1): 3-10. [Online]. Available: Wikipedia

[6] Dyah Marganingrum, "Jejak Ekologis Kawasan Regional Bandung," Jurnal Teknologi Lingkungan, vol. 29, no. 2. 2019.

[7] I Made Wirartha, "Metode Penelitian Sosial Ekonomi," (to be published).

[8] Public Works Department of Medan City, 2015, Document of Rencana Program Investasi Infrastuktur Jangka Menengah (RPI2JM). [Online]. Available: http://sippa.ciptakarya.pu.go.id/sippa_online/ws_file/dokumen/rpi2jm/DOCRPIJM_150419 2899Bab_05_Keterpaduan_Strategi_Pengembangan_Kota_Medan.pdf. [Accessed: Oct. 28, 2020].

[9] A. B. Fuadi, Y. Sumitra, S. Nasril, A. Handre, "Perancangan Taman Edukasi Botani dan Hutan Kota di Kawasan Delta Malvinas Padang" (to be published).

[10] P. A. D Fadilah, D. H. Heriyanto, T. J. Daryanto, "Pengembangan Kawasan Wisata Waduk Kedung Ombo Sebagai Wisata Terpadu Di Kabupaten Sragen Dengan Pendekatan Ekologi Arsitektur,” Jurnal Ilmiah Arsitektur Dan Lingkungan Binaan, vol. 12, no. 2. 2014.

[11] A. Anggesi, P. Aldy and R. Amanati, "Adventureland Di Pekanbaru Dengan Pendekatan Ekologi Arsitektur" (to be published).

[12] Ken Yeang, Designing With Nature: The Ecological Basis for Architectural Design. McGraw-Hill, 1995. [Online] Available: Google Play e-book.

[13] E. W. Goerge, H. Mair, and D. G. Reid, "Rural Tourism Development: Localism and Cultural Changes" (to be published).

[14] Gunn, C. A. And T. Var, "Tourism Planning: Basics, Concepts and Cases" (to be published).

[15] A. Nurfiarni, "Rancangan Pengembangan Suaka Perikanan (Fish Sanctuary) Estuari Berbasis Sistem Sosial - Ekologi di Segara Anakan, Kabupaten Cilacap, Disertasi" (to be published).

[16] Muliani, L. Adrianto, K. Soewandi, S. Hariyadi, "Sistem Sosial Ekologi Kawasan Desa Pesisir Kabupaten Subang," Jurnal Ilmu dan Teknologi Kelautan Tropis, vol. 10, no. 3. 2018.

[17] F. Heinz, Arsitektur dan Lingkungan. Kanisius Publisher, 2009. [Online] Available: www.pustaka78.com 